\title{
Pengembangan Aplikasi Sizisku 1.0 Untuk Meningkatkan Optimalisasi Pengelolaan Lembaga Zakat Nasional
}

\author{
Selvi Sehiling ${ }^{1}$, Firza Oktavia Nurul Kumala ${ }^{2}$, Khoirul Anas ${ }^{3}$, Ahmad Ajib Ridlwan ${ }^{4}$ \\ Universitas Negeri Surabaya \\ sehilings@gmail.com
}

\begin{abstract}
The potential of receiving zakat, infak and alms in Indonesia is quite large. That is because the majority of Indonesia's population is Moslem, reaching 207.2 million people (BPS, 2017). On the other hand, the number of poor people in Indonesia is also quite alarming, reaching 27.77 million people (BPS, 2017). Therefore, it is expected that the potential of receiving zakat, infak and alms can be managed as well as possible so that the benefits can be optimal as a counterweight to the country's economic sector. This paper aims to present the idea of an android-based application development product named SIZISKU. This application is a new idea that aims to improve the optimization of zakat, infak and alms management by integrating national zakat institutions. By integrating national zakat institutions in an integrated application, the mustahik (the receivers of zakat, infak, and alms) database of all zakat institutions can be collected. By that way, it can avoid overlapping zakat recipients from the same institution. It also makes the distribution of zakat, donations and alms can be delivered equally. In addition, the purpose of this paper is to find out what the stages to develop the application and who are the parties involved to implement it. The result of this writing is the prototype of the SIZISKU application.
\end{abstract}

Keywords : $\quad$ SIZISKU, application, Zakat Nasional.

\section{Latar Belakang}

Salah satu negara dengan penduduk muslim terbesar di dunia adalah negara Indonesia. Berdasarkan data dari Badan Pusat Statistika Nasional (2017), jumlah penduduk muslim di Indonesia mencapai 207,2 juta jiwa atau sekitar $87,2 \%$ dari total penduduk. Adapun persentase jumlah umat muslim Indonesia dari umat muslim di dunia adalah sebesar 13,1\%. Dengan jumlah tersebut, bangsa Indonesia hingga saat ini masih dihantui problematika kehidupan yang kompleks, seperti kemiskinan, kebodohan dan keterbelakangan. Kemiskinan adalah salah satu sebab adanya kesenjangan sosial. Berdasarkan data Badan Pusat Statistika Nasional pada bulan Maret 2017, jumlah penduduk miskin di Indonesia mencapai 27,77 juta orang atau 10,70\% dari jumlah penduduk, angka tersebut bertambah sebanyak 6,90 ribu orang dibandingkan dengan kondisi September 2016 yang sebesar 27,76 juta orang atau 10,64 \% dari jumlah penduduk (BPS, 2017). Dalam hal ini diperlukan dana besar untuk menanggulangi kemiskinan. Oleh 
karena jumlah penduduk muslim yang besar, maka potensi penerimaan zakat di Indonesia sebagai penyeimbang sektor ekonomi juga besar.

Zakat adalah salah satu sektor penting dalam menunjang perekonomian negara. Menurut Kamus Besar Bahasa Indonesia (2016), zakat yaitu jumlah harta tertentu yang wajib dikeluarkan orang yang beragama islam dan diberikan kepada golongan yang berhak menerima (fakir miskin dan sebagainya) menurut ketentuan yang ditetapkan oleh syara'. Sedangkan sedekah merupakan pemberian sesuatu kepada fakir miskin atau orang-orang yang memiliki hak untuk menerimanya, di luar kewajiban zakat dan zakat fitrah sesuai dengan kemampuan pemberi atau juga bisa disebut sebagai infak.

Berdasarkan Studi PIRAC, setiap tahun potensi penerimaan zakat pada umumnya akan mengalami peningkatan. Pada tahun 2007, PIRAC mengungkap bahwa potensi zakat rata-rata setiap muzaki mencapai Rp 684.550. angka tersebut mengalami peningkatan dari tahun 2004 lalu yakni sebesar Rp 416.000. angka tersebut didapatkan dari hasil survei di 10 kota besar yang ada di Indonesia. Lebih lanjut, pada tahun 2009 diproyeksikan potensi menghimpunan zakat mampu mencapai Rp 12,7 Trilliun. Angka tersebut didapatkan dari FEBS FEUI yang menggunakan pendekatan jumlah muzaki dari populasi muslim di Indonesia dengan asumsi jika sebanyak $95 \%$ penduduk muslim di Indonesia membayar zakat.(Indonesia Economic Outlook, 2010).

Namun perlu diketahui bahwa potensi penerimaan zakat yang telah dipaparkan pada paragraf sebelumnya, belum diimbangi dengan penghimpunan dana zakat di lapangan. Tingkat kesenjangan yang cukup tinggi antara potensi penerimaan dengan penghimpunan dana zakat telah dibuktikan dari data aktual dari OPZ resmi tahun 2015 terkait penghimpunan zakat, infak dan sedekah yang penerimaannya baru mencapai Rp 3,7 triliun atau kurang dari 1,3\% dari potensinya (Outlook Zakat Indonesia, 2017).

Disamping itu potensi zakat juga belum diiringi dengan adanya peningkatan efektifitas maupun efisiensi dari kinerja amil zakat itu sendiri. Perzakatan nasional masih banyak tantangan dan permasalahan yang harus segera di perbaiki agar pengelolaan ZIS dapat optimal. Adapun tantangan dan permasalahn tersebut anata lain kurangnya penataan sistem zakat, terbatasnya sinergi, terbatasnya integrasi dari seluruh LPZ Nasional, serta kajian dan penelitian yang minim (Outlook Zakat Indonesia, 2010). Tidak hanya itu, integrasi data dari seluruh LPZ di Indonesia juga belum saling terintegrasi. Oleh karena itu, sering terjadi tumpang tindih mustahik dalam menerima zakat yang mengakibatkan distribusi zakat tidak optimal dan tidak merata. Dari paparan diatas, maka penulis tertarik untuk menggagas sebuah ide aplikasi berbasis android yang bernama SIZISKU. Adapun android itu sendiri yaitu sebuah sistem operasi yang berbasis linux dimana dapat digunanakan diberbagai perangkat mobile.

Tujuan utama dari android yaitu meningkatkan kemajuan inovasi telepon agar pemakai dapat lebih mengeksplorasi kemampuan serta pengalaman yang lebih apabila dibandingkan dengan beberapa platform mobile lain. Hingga saat ini android terus berkembang baik secara sistem maupun aplikasinya (Rifa'atunnisa, 2014; Eri Satria, 2014; Rinda Cahyana, 2014). Dari paparan diatas, maka munculah sebuah pertanyaan tentang bagaimana sistem kerja aplikasi SIZISKU, bagaimana langkah-;angkah dalam mengembangan aplikasi SIZISKU, serta siapa saja stakeholder yang akan terlibat dalam implementasi aplikasi ini. 


\section{Teori dan Metode}

\subsection{Kajian Teori}

\subsubsection{Zakat, Infaq, Shodaqah}

Menurut bahasa, Zakat memiliki beberapa makna salah satunya yakni suci. Sedangkan menurut Undang-Undang No. 38 Tahun 1998 tentang Pengelolaan Zakat, pengertian zakat adalah harta yang wajib disisihkan oleh seorang muslim atau badan yang dimiliki oleh orang muslim sesuai ketentuan agama untuk diberikan kepada yang berhak menerimanya. Dalam Al-Quran Surah At-Taubah ayat ke 60 diterangkan bahwa "Sesungguhnya zakat itu adalah untuk orang fakir, orang miskin, amil (pengurus zakat), mualaf, untuk (memerdekakan) budak, orang yang berutang, orang yang berjuang di jalan Allah, dan orang yang sedang dalam perjalanan (untuk keperluan yang baik) sebagai suatu ketetapan yang diwajibkan Allah dan Allah Mahamengetahui lagi Mahabijaksana”.

Dengan berzakat, maka dapat menurunkan angka kemiskinan di Indonesia melalui pemerataan pendapatan yang dikenal dalam Islam (Canggih et al., 2017). Berdasarkan hasil dari penelitian (Athoillah, 2014) seorang pakar ekonomi zakat yang dilakukan di 6 provinsi, pada tahun 2011-2012 diketahui perolehan dana zakat sangat meningkat yang menjadikan data penduduk miskin mengalami penurunan.

Infak artinya menyisihkan sebagian harta. Jika zakat ada nishabnya yakni hanya boleh diperuntukan kepada 8 asnaf seperti yang telah dijelaskan pada QS. 9 : 60, namun Infak tidak. Infak dikeluarkan oleh setiap orang yang beriman baik dalam keadaan lapang maupun dalam keadaan sempit (Qs. Ali Imran: 143). Menurut syariat, infak didefinisikan sebagai pengeluaran untuk kepentingan masyarakat luas yang dianjurkan oleh ajaran Islam. Infak dapat diberikan untuk siapa saja, misalnya untuk mebelikan makan teman, menyumbang kegiatan amal dan lain sebagainya.

Pada dasarnya sedekah hampir sama dengan infak, namun memiliki pengertian yang lebih luas dari pada infak. Sedekah tidak hanya berupa hal-hal yang bersifat materiil seperti benda fisik atau uang namun juga dapat berupa senyuman, bacaan tahmid, bantuan jasa, maupun kalimah thayyibah lainnya. .Adapun infak, bukanlah seperti demikian. Sedekah menurut etimologi berasal dari kata "sedekah" yang dapat didefinisikan sebagai pemberian seorang muslim kepada orang lain secara ikhlas dan sukarela tanpa dibatasi oleh waktu dan jumlah tertentu. Menurut etimologi, sedekah itu sendiri berasal dari kata "sedekah" yang artinya seorang muslim memberi secara ikhlas yang tidak dibatasi oleh waktu, jumlah dan konsidi tertentu seperti halnya zakat.

\subsubsection{Lembaga Pengelola Zakat}

Organisasi Pengelola Zakat adalah institusi melakukan kegiatanya di bidang pengelolaan zakat, infak dan shadaqah. Keberadaan organisasi ini diatur dalam UU No. 38 Th 1999 tentang pengelolaan zakat. Adapaun organisasi pengeloaan zakat ada 2 jenis, yaitu :

1. Badan Pengelola Zakat

Organisasi pengelola zakat yang dibentuk oleh pemerintah.

2. Lembaga amil zakat

Organisasi pengelolaan zakat yang telah dikukuhkan oleh pemerintah namun dibentuk oleh masyarakat sepenuhnya. 
Berkaitan dengan adanya Lembaga Pengelola Zakat dan Lembaga Amil Zakat yang menjadi wadah pemberdayaan umat harus dikelola secara profesional dan terorganisir khususnya yang berkaitan langsung dengan tugas pokoknya yakni pengumpulan, pengelolaan, pendistribusian dan pendayagunaan.

\subsection{Metode Penelitian}

Karya tulis ini ditulis dengan cara menjawab rumusan masalah yang akan dikaji. Pengkajian masalah untuk menciptakan solusi pada penulisan ini dilakukan dengan membaca literatur yang sesuai. Sedangkan metodenya menggunakan studi pustaka yang kemudian akan diselaraskan dengan konsep ide dan permasalahan yang ada.

Adapun pengembangan aplikasi SIZISKU menggunakan model waterfall Development Model atau biasa disebut Model Sekuensial Linier. Model Pengembangan ini termasuk dalam model pendekatan pengembangan perangkat lunak sekuensial yang mempunyai tigkat kemajuan sistem pada tahapan analisa, desain, kode, pemeliharaan dan pengujian.

$\begin{array}{|c}\text { analisa } \\ \text { permasalahan dan } \\ \text { rekayasa sistem }\end{array}>$ Desain $\left.\left.\quad>\begin{array}{c}\text { Penulisan } \\ \text { Kode } \\ \text { Program }\end{array}\right\rangle \begin{array}{c}\text { Pengujian } \\ \text { Program }\end{array}>\begin{array}{c}\text { Perawatan } \\ \text { Program }\end{array}\right\rangle$

Gambar 5. Tahap Pengembangan Model LSM

Rekayasa Sistem dan Analisis, Tahap ini adalah tahap menyiapkan semua kebutuhan software yang didalamnya juga menentukan kegunaan software yang sesuai dengan tujuannya. Pada tahap ini, penulis melakukan diskusi bersama tim dan dosen ahli untuk menganalisis masalah dan kebutuhan masyarakat terkait Zakat, Infak, dan Sedekah.

Desain sistem, pada tahap ini dilakuan sebelum proses pengkodean program. Tahap ini bertujuan untuk memberikan gambaran terkait persiapan yang harus dikerjakan dan seperti apakah tampilan aplikasi. Disisi lain, tahap ini membantu dalam mendefinisikan arsitektur sistem secara keseluruhan. dalam hal ini, penulis menggunakan software corel draw X5 dalam mendesain.

Penulisan Kode Program adalah tahap untuk melakukan pemograman. Cara dalam pembuatan software ini dilakukan dengan membuat modul kecil yang akan digabungkan untuk ke proses tahapan berikutnya.Dalam tahap ini juga terdapat pemeriksaan modul untuk pengujian fungsi yang diinginkan.

Uji coba program dengan meggabungkan modul yang dibuat, tahapan berikutnya yaitu pengujian software untuk mengetahui kesesuaian desain. Pada saat pengujian, penulis akan meminta bantuan dari dosen ahli Teknologi Informatika untuk menguji aplikasi SIZISKU.

Perawatan Program, Proses ini merupakan tahapan terakhir dalam bentuk model sekuensil linier. Aplikasi yang telah dijalankan selanjutnya akan dilakukan pemerliharaan terhadap perbaikan kesalahan yang tidak terdeteksi padatahapan sebelumnya.

Penulisan karya tulis ilmiah ini menggunakan sumber data yang diperoleh melalui studi pustaka yaitu dengan menggunakan obyek kajian penelitian dari jurnal, artikel imliah, maupun literatur dari internet yang relevan dengan pembahasan masalah.

Data yang telah terkumpul dari hasil kajian literatur selanjutnya digunakan sebagai pijakan dalam melakukan analisis. Analisis tersebut dilakukan secara kualitatif 
yang selanjutnya dapat ditarik kesimpulan berdasarkan pembahasan dari setiap permasalahan yang dikemukakan. Teknik analisis data dalam penulisan ini meliputi :

1. Pengumpulan data, data yang berasal dari google form, jurnal, artikel ilmiah maupun literatur yang bersumber dari internet dikumpulkan untuk kemudian diambil bagian-bagian yang relevan dengan topik yang dibahas.

2. Reduksi data, merupakan analisis yang berfungsi menajamkan, menggolongkan, membuang yang tidak perlu, dan mengorganisasikan data sehingga diperoleh kesimpulan akhir dari data yang diperoleh.

3. Penarikan kesimpulan, bertujuan untuk menjawab rumusan masalah penulisan ini yang diuraikan secara detail.

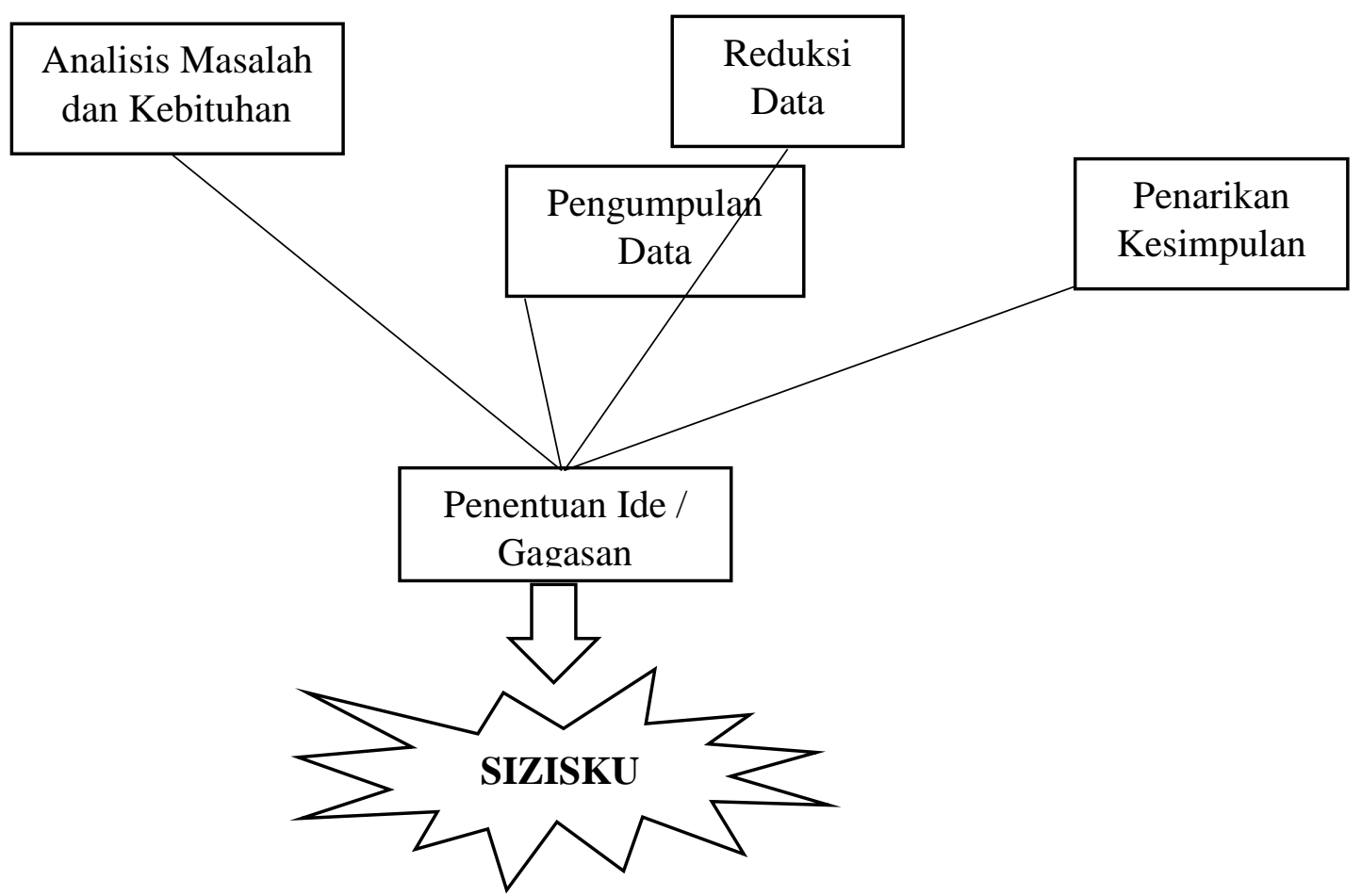

Gambar 1. Kerangka Berpikir

\section{Hasil dan Pembahasan}

3.1 Sistem kerja SIZISKU (Sistem Informasi Zakat Infak dan Sedekah Terpadu) : Integrasi Lembaga Zakat Nasional Sebagai Upaya Optimalisasi Pengelolaan Lembaga Zakat Berbasis Android

1. Tentang SIZISKU (Sistem Informasi Zakat Infak dan Sedekah Terpadu)

Secara konseptual peran teknologi internet dalam penghimpunan dana zakat, dapat memperluas daya jangkau amil dalam mengakses muzakki, begitu juga sebaliknya. Disisi lain, penggunakan teknologi internet ini juga mempermudah amil dalam pengontrolan program serta mengawasi perkembangan masyarakat yang ikut serta dalam program. Sehingga pemanfaatan dana ZIS optimal dan proses peningkatan kesejahteraan masyarakat miskin lebih terpantau dengan baik (Winda Afriyenis DKK, 2018). Namun, peran internet yang mampu mempermudah pengelolaan zakat, infak dan sedekah tidak menjamin penyaluran tersebut dapat terdistribusi secara merata serta tidak terjadi tumpang tindih mustahik. Oleh karena itu, diperlukan pula aplikasi yang mengintegrasikan lembaga pengelola zakat nasional agar pengelolaan dan distribusi 
zakat, infak, sedekah bisa merata kepada masyarakat luas dan tidak terjadi penerimaan ZIS ganda oleh setiap mustahik.

SIZISKU merupakan aplikasi berbasis android yang mengintegrasikan lembaga pengelola zakat di Indonesia menjadi sebuah aplikasi terpadu dengan tujuan mengoptimalkan peran serta potensi zakat itu sendiri. Aplikasi ini menjadi perantara langsung antara donatur dan lembaga dimana zakat atau dana yang didonasikan masyarakat melalui aplikasi SIZISKU otomatis terkirim ke lembaga pengelola zakat yang dipilih. Sehingga SIZISKU tidak perlu menimbun dana masyarakat. Disisi lain, di aplikasi ini terdapat database seluruh data mustahik dan program yang dikelola oleh masing-masing lembaga zakat. Sistem otomatis menolak data mustahik yang dikelola lembaga zakat yang sama. Dengan integrasi data tersebut, maka menghindari tumpang tindih mustahik dalam menerima zakat.

Lembaga pengelola zakat dapat mendaftarkan diri melalui aplikasi SIZISKU untuk menghimpun dana dari masyarakat serta mengkampanyekan programprogramnya melalui aplikasi ini. Tidak hanya itu, lembaga zakat yang sudah terdaftar di aplikasi diharuskan untuk mengunggah database mustahik yang dinaunginya. Hal ini dimaksudkan untuk menghindari tumpang tindih dalam menyalurkan zakat kepada mustahik. Dengan begitu, maka zakat, infak dan shodaqoh dapat didistribusikan secara merata kepada masyarakat luas dan tidak terpaku pada beberapa orang atau daerah tertentu saja.

Tidak hanya lembaga pengelola zakat saja yang dapat mengakses, namun masyarakat juga bisa menggunakan aplikasi ini dengan cara registrasi terlebih dahulu. Masyarakat dapat menyalurkan zakat, infak dan sedekahnya kepada lembaga zakat tertentu yang telah ia percaya untuk mengelolanya. Disisi lain, jika masyarakat belum pernah menyalurkan ZISnya melalui lembaga pengelola zakat, maka masyarakat bisa mempertimbangkan maupun membandingkan kinerja atau history dari masing-masing lembaga zakat melalui laporan keuangan yang tersedia di aplikasi SIZISKU. Hal ini dimakasudkan agar terdapat transparansi dan menghindari penyalahgunaan wewenang dari lembaga pengelola zakat.

2. Desain SIZISKU ((Sistem Informasi Zakat Infak dan Sedekah Terpadu)

Pada saat membuka aplikasi, jendela yang akan muncul pertama kali adalah laman login dan register. Laman ini akan menampilkan logo SIZISKU serta bantuan.

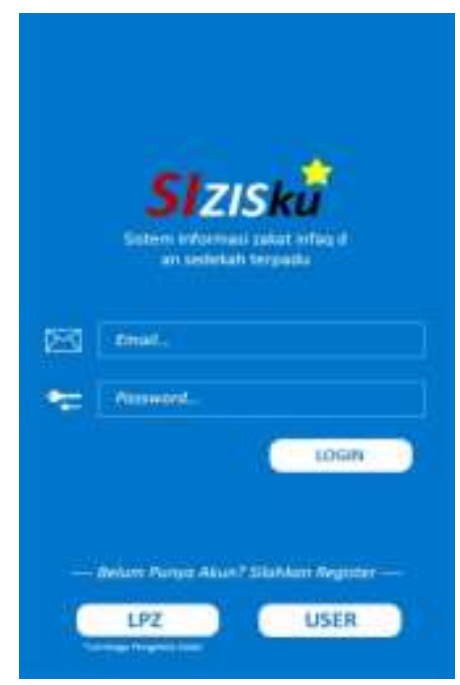

Gambar 1. Laman Login dan register 
Pada saat register, pengguna bisa memilih sebagai Lembaga Pengelola Zakat ataukah pengguna biasa yang berperan sebagai muzaki atau donatur. Jika memilih sebagai lembaga zakat, maka form register yang harus diisi terkait data-data lembaga. Apabila memilih sebagai user atau masyarakat umum maka form register berisi terkait data-data pengguna tersebut.

Tampilan utama akan terlihat setelah user atau lembaga zakat login di aplikasi SIZISKU, terdapat beberapa menu pada tampilan ini yaitu menu lembaga-lembaga zakat, menu program-program khusus lembaga pengelola zakat, menu rekomendasi mustahik, menu lintasan dan menu upload database (khusus muzakki).

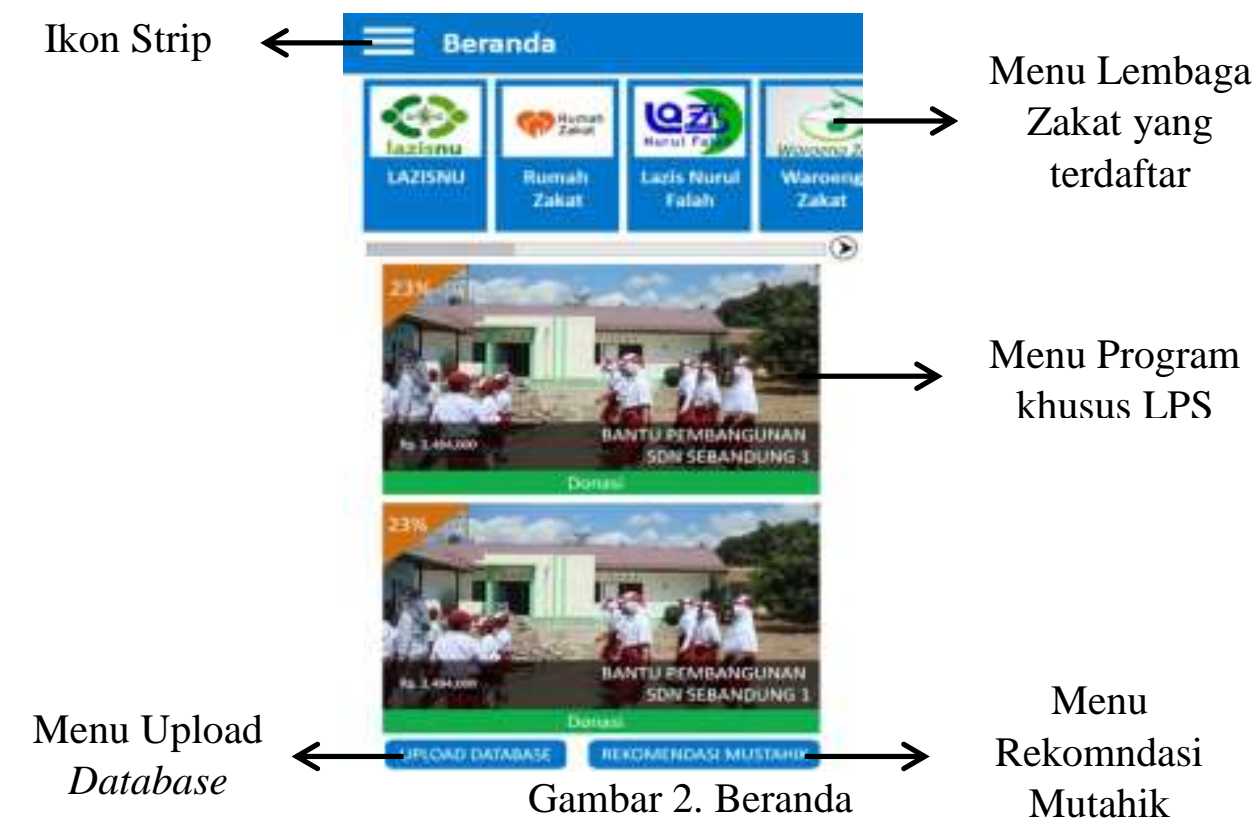

menu lembaga-lembaga zakat, masyarakat dapat memilih lembaga zakat mana yang dipercayai untuk menghimpun dan mendistribusikan dananya kepada yang membutuhkan. Setelah masyarakat menekan menu ini, maka akan nampak logo dan deskripsi lembaga pengelola zakat (LPZ) yang dipilih serta menu donasi. Jika masyarakat klik menu donasi di jendela ini, itu artinya muzakki atau donatur telah mempercayai lembaga zakat tersebut untuk mengelola zakat, infak ataupun sedekahnya. Kemudian masyarakat dapat memilih jenis-jenis donasinya, mengisi nama donatur atau menyembunyikannya serta nominal zakat, infak atau sedekahnya. Setelah muzakki mengklik lanjutkan, maka akan nampak jendela bukti pembayaran dengan tujun untuk mengkonfirmasi bahwa data serta nominal yang diisikan sudah benar. Tahap terakhir adalah memilih metode pembayaran melalui transfer bank atau online. Jika muzaki telah melakukan pebayaran, maka akan otomatis mendapatkan email maupun sms dari lembaga zakat bahwa dana muzaki maupun donatur telah diterima oleh lembaga pengelola zakat yang telah dipilih (desain donasi terdapat pada lampiran 2).

menu program bertujuan untuk mengkampanyekan program-program khusus dari lembaga pengelola zakat. Pada menu ini, dana dari donatur akan secara otomatis untuk kegiatan program yang telah ditentukan seperti bantuan kepada palestina, sedekah untuk orang sakit kanker, donasi pembangunan panti jompo dan lain-lain. Program tersebut akan dinaungi oleh satu lembaga

zakat saja, sehingga tidak akan terjadi pengelolaan ganda yang mengakibatkan distribusi dan potensi dari zakat, infak dan sedekah tidak maksimal. Sistem akan 
otomatis menolak program dari LPZ jika program tersebut telah dikelola oleh LPZ lain (desain program LPZ terlampir pada lampiran 3).

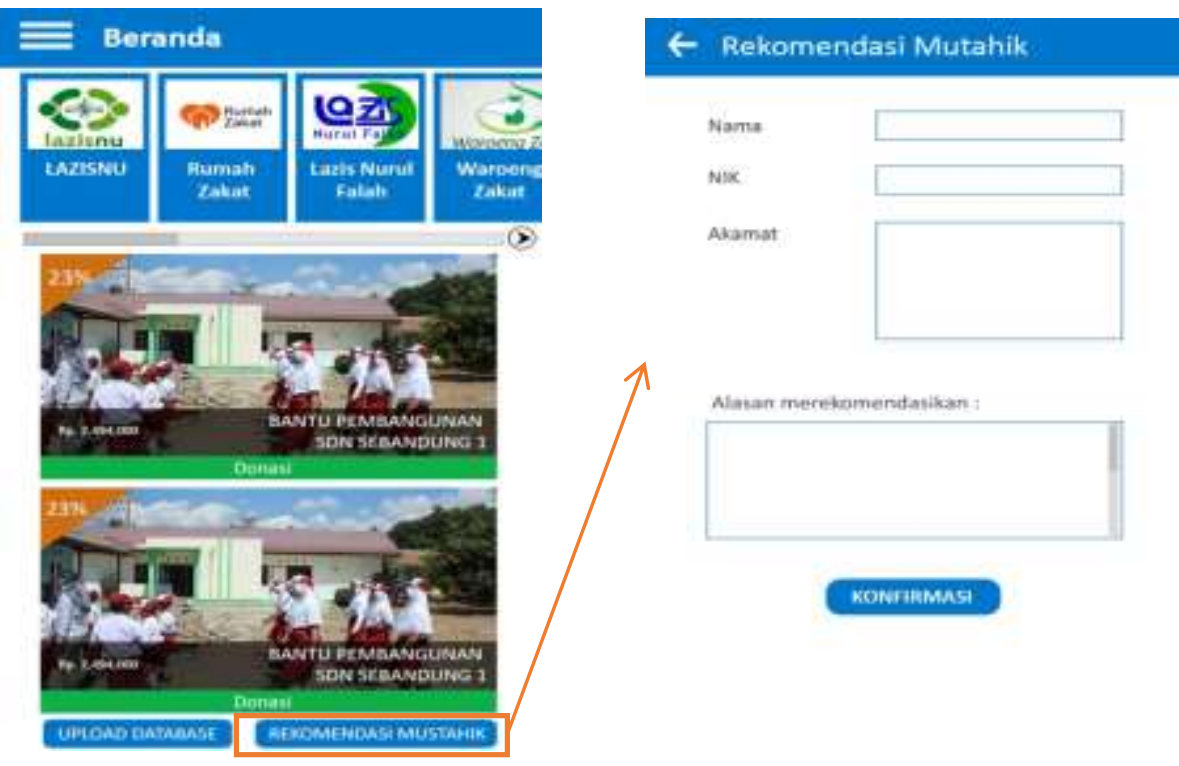

Gambar 3. Rekomendasi mustahik

pada bagian pojok kanan bawah, terdapat menu rekomendasikan mustahik. Dimana pada menu ini, masyarakat dapat merekomendasikan pihak yang berhak untuk menerima zakat, infak atau sedekah namun masih belum dinaungi oleh lembaga pengelola zakat. Misalkan terdapat anak disabilitas yang membutuhkan bantuan, namun hingga kini belum menerima bantuan dari siapaun, sehingga masyarakat dapat merekomendasikan orang tersebut. Jika orang tersebut telah direkomendasikan, maka LPZ akan menerima pemberitahuan otomatis oleh sistem bahwa ada masyrakat yang merekomendasikan calon mustahik baru yang harapanya dapat dinaungi oleh LPZ tertentu.

Ikon strip sebagai pintasan, ikon ini akan dihubungkan dengan menu lainya yaitu profil pengguna, history donasi, atur pengingat, FAQ dan tentang SIZISKU. Jika pengunjung mengklik salah satu menu pada icon tersebut, maka pengguna akan langsung dihubungkan pada menu tersebut (desain ikon pintasan terdapat pada lampiran 4).

Menu history donasi bertujuan untuk memberikan informasi kepada muzakki atau donatur yang telah menyalurkan dananya untuk masyrakat yang berhak menerima kepada lembaga zakat. Dengan begitu, maka mereka akan mengetahui informasi terkait aliran dananya (desain history donasi terdapa pada lampiran 5). 


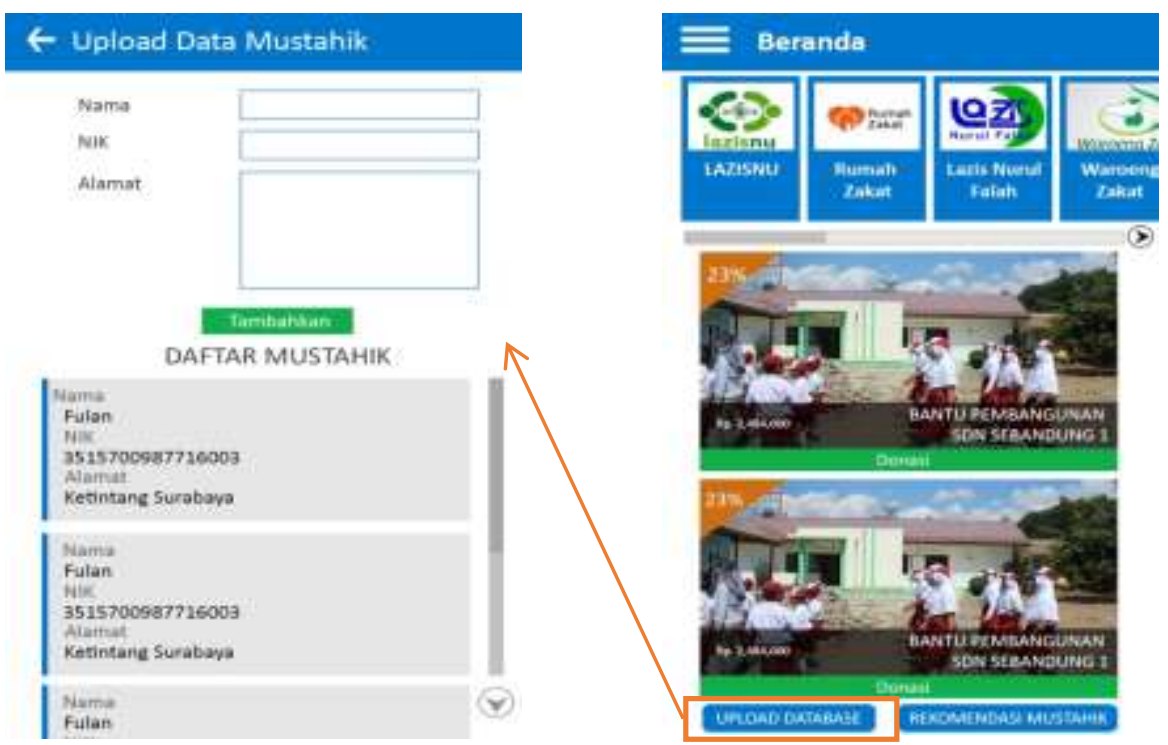

Gambar 4. Unggah database mustahik

Menu upload database berfungsi untuk menghimpun data-data mustahik dari setiap lembaga zakat nasional. Tujuan menghimpun data-data tersebut adalah untuk menghindari tumpang tindih penyaluran zakat dari LPZ kepada mustahik. Dengan begitu, maka distribusi zakat nasional bisa merata. Pada saat mengunggah daftar mustahik, sistem otomatis akan menyimpan data tersebut dengan Nomor Induk Keluarga (NIK) sebagai kata kuncinya. Jika data tersebut telah di unggah oleh lembaga lain, maka sistem otomatis akan menolaknya.

\subsection{Pihak-pihak yang terlibat dalam implementasi SIZISKU (SISTEM INFORMASI ZAKAT INFAK dan SEDEKAH TERPADU)}

Adapun pihak-pihak yang terlibat untuk mengimplementasikan aplikasi ini yaitu :

1. Pemerintah

Pemerintah dalam hal ini adalah Kementrian Agama, dimana kementrian agama memiliki tugas untuk mengelola dan menangani aspek regulasi terkait distribusi Zakat, Infak dan Sedekah. Disamping itu, juga bertanggung jawab dalam proses perizinan lembaga zakat, audit syariah, dan hukum pelaksanaan dalam pengawasan lembaga pengelola zakat. Reposisi peran Kementerian Agama sangat dinanti sebagai langkah mewujudkan pengelolaan zakat yang dapat dipercaya, akuntabel, transparan dan bermanfaat bagi umat

2. Lembaga Pengelola Zakat

Lembaga zakat berperan untuk menghimpun dana dari masyarakat kemudian didistribukan pula kepada masyarakat yang berhak untuk menerima zakat yaitu fakir, miskin, amil atau pengurus-pengurus zakat, orang-orang yang berhutang dan tidak mampu membayar, mereka yang sedang dalam perjalanan, orang yang berjuang di jalan Allah, muallaf, dan budak. Disamping itu, LPZ juga berperan untuk merumuskan sebuah program serta mediator para penyandang dana.

3. Muzakki

Muzakki menjadi bagian yang tidak terpisahkan dalam mengimplementasikan aplikasi ini. muzakki dibebani kewajiban untuk mengeluarkan bagian tertentu dari harta kekayaannya kepada 8 asnaf yang biasa disebut mustahik. Melaui 
Media lembaga pengelola zakat yang tersedia dalam aplikasi sizisku agar lebih mudah dalam pendistribusian zakat.

4. Mustahiq

Mustahik merupakan 8 asnaf yang menjadi bagian terpenting dalam pengelolaan zakat. Dalam hal ini mustahik dapat menggunakan aplikasi dan mengajukan diri untuk masuk ke database lembaga pengelola zakat.

5. Programmer

Programmer merupakan orang yang berpengaruh dalam pengelolaan aplikasi ini. Peran programmer dalam hal ini selain membuat sistem aplikasi juga mengembangkan aplikasi

6. Masyarakat umum

Dalam hal ini dukungan masyarakat sangat penting dalam berjalannya sistem aplikasi, semakin banyak masyarakat yang mengetahui aplikasi ini semakin banyak pula yang berkontribusi terhadap pengelolaan zakat, infak dan sedekah di indonesia.

\section{Simpulan}

Zakat, infak dan sedekah merupakan salah satu sektor penting guna menunjang perekonomian negara. Namun pendistribusianya belum merata dan sering terjadi tumpang tindih mustahik dikarenakan tidak adanya data gabungan antar lembaga pengelola zakat nasional. Aplikasi SIZISKU merupakan sebuah aplikasi berbasis android yang mengintegrasikan lembaga-lembaga pengelola zakat di Indonesia menjadi sebuah aplikasi terpadu. Pada aplikasi ini terdapat menu upload database yang berfungsi untuk menghimpun data-data mustahik oleh masing-masing lembaga yang berfungsi untuk mencegah penyaluran zakat, infak dan sedekah kepada mustahik yang sama. Disamping itu terdapat menu rekomendasikan mustahik yang berfungsi untuk mengajukan mustahik baru yang belum dinaungi oleh lembaga zakat. Aplikasi ini dikembangkan dengan model sekuensial linier yang terdiri dari 5 tahapan yaitu tahapan analisa, desain, pengkodean program, pengujian, dan pemeliharaan. Disamping itu, untuk mengimplementasikan SIZISKU maka dibutuhkan keterlibatan beberapa pihak antara lain pemerintah, lembag penglola zakat, muzaki, mustahik, programer dan masyrakat umum.

\section{Saran}

Sebagai seorang muslim, ketika kita diberikan rezeki yang berlebih hendaknya saling membantu dengan cara berzakat, infak dan sedekah. Hal tersebut dapat menjadi solusi atas permasalahan kesenjangan sosial. Sebaiknya pengelolaan zakat harus lebih optimal agar tidak terjadi penerimaan ganda terhadap mustahik yang sama, melalui cara pemanfaatan sumberdaya maupun pengintegrasian lembaga zakat. Ditinjau dari segi aplikasi, SIZISKU merupakan ide pokok dalam mengintegrasikan lembaga pengelola zakat di Indonesia. Pengembangan aplikasi ini kedepanya sangat diharapkan misalkan diadaptasi ke playstore dan dikelola lebih lanjut oleh kementrian agama. Diharapkan bantuan dan kerjasama dari semua pihak demi kelancaran implementasi SIZISKU untuk kebermanfaatan umat. 


\section{Daftar Pustaka}

Athoillah, anton. 2014. Zakat Untuk Kesejahteraan Bangsa. Ar-raniry. 16(2). Jakarta

Atika, Nur. 2017. Optimalisasi Strategi Pengelolaan Zakat Sebagai Sarana Mencapai Kesejahteraan Masyarakat. Skripsi. Universitas Islam Negeri Alauddin

Badan Pusat Statistik. 2017. Berita Resmi Statistik: Profil Kemiskinan di Indonesia. No. 66/07/Th.XX, 17 Juli. Halaman 2-3. Jakarta

Canggih, C., Fikriyah, K., \& Yasin, A. (2017). Potensi Dan Realisasi Dana Zakat Indonesia. Al-Uqud: Journal of Islamic Economics, 1(1), 14-26

Jayani, Jadya. 2019. Jumlah Penduduk Indonesia 269 Juta Jiwa Terbesar Keempat Di Dunia. Diakses 11 september 2019 pada web katadata.com

Kamus Besar Bahasa Indonesia. [Online]. tersedia di kbbi.kemendikbud.go.id/entry.zakat. diakses tanggal 08 september 2019

Ramadhita. 2012. Optimalisasi Peran Lembaga Amil Zakat Dalam Kehidupan Sosial. Jurisdictice: Jurnal Hukum dan Syariah, 3(1), hlm 24-34. Jakarta

Rifa'atunnisa, dkk. 2014. Pengembangan Aplikasi Zakat Berbasis Android Menggunakan Metode Prototype. Jurnal Agoritma, 11(1), 2

Tim penyusun. 2017. Outlook Zakat.Jakarta : Pusat Kajian Strategis BAZNAS

Tim penyusun. 2010. Outlook Zakat.Jakarta : Pusat Kajian Strategis BAZNAS

Undang-Undang No. 38 Tahun 1998 tentang Pengelolaan Zakat

Afriyenis, Winda. Anita Ade R., dan Febri Aldi. 2018. Implementasi Teknologi Informasi Dan Komunikasi Dalam Zakat Untuk Meningkatkat Kesejahteraan Masyarakat Miskin. Jurnal Ekonomi dan Bisnis Islam Volume 3(2) (hlm. 231) 


\section{LAMPIRAN}

Lampiran 1. Laman login dan register

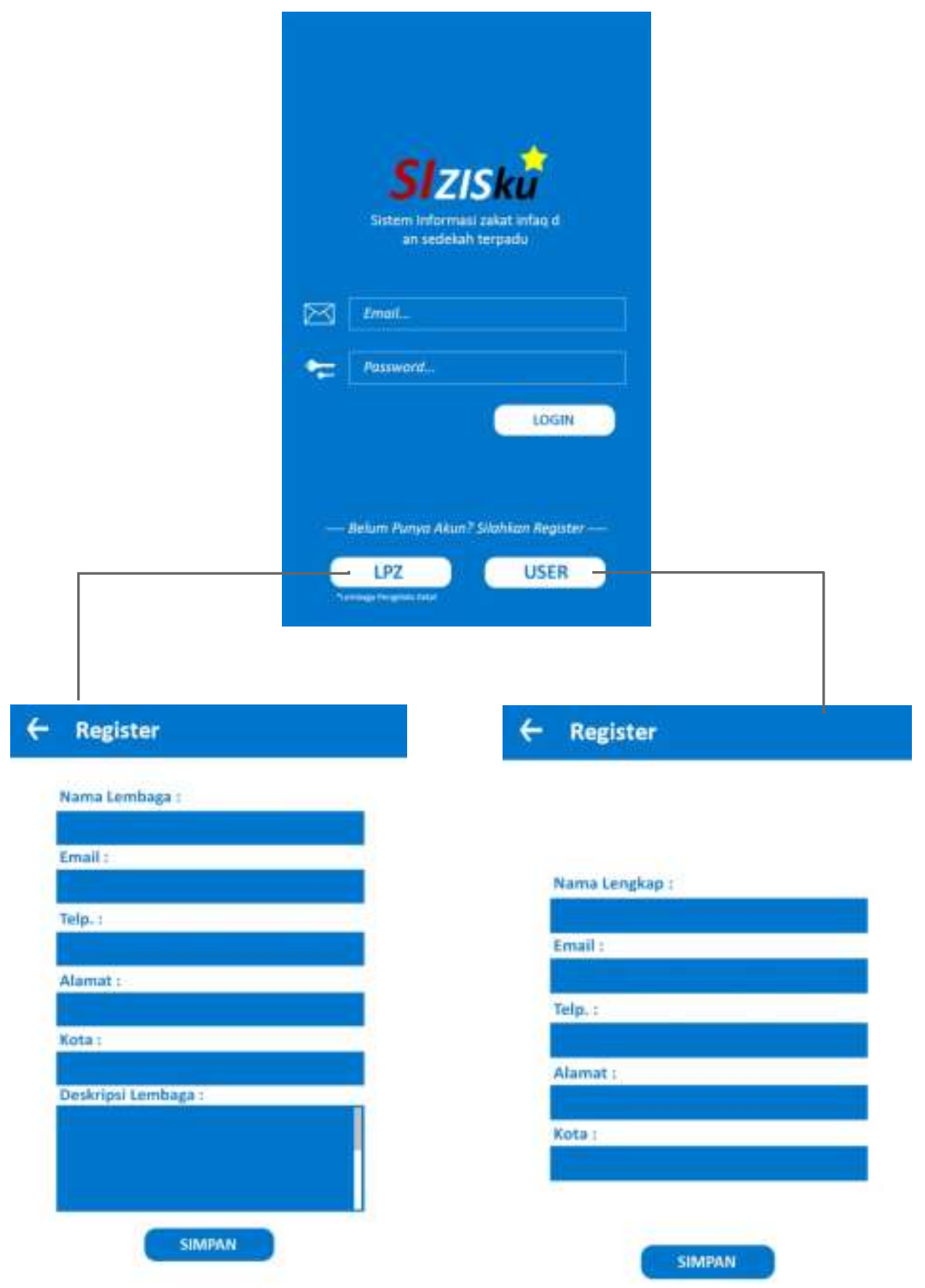


Lampran 2. desain donasi

\section{Detail Lembaga}

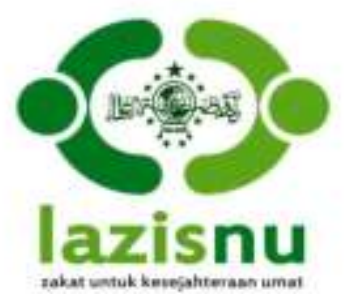

LAZISNU

"Deskripsi Lembaga

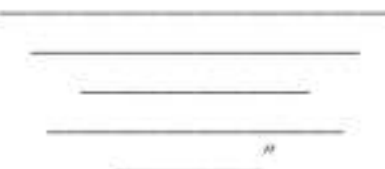

DONASI

\section{$\leftarrow$ Donasi}

$\begin{array}{ll}\square \text { Zakat Maal } & \square \text { Zakat Fitrah } \\ \square \text { Sedekah } & \square \text { Wakaf Tunai } \\ \square \text { Qurban untuk } & \square \text { Aqiqah untuk } \\ \text { Desa Miskin } & \text { Desa Miskin }\end{array}$

Atas Nama...

Sembunyikan Nama Muzakki

Nominal (Rp.)

Pesan....

\section{Lanjutkan}

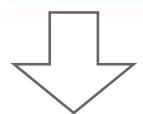

\section{$\leftarrow$ Detail Donasi}

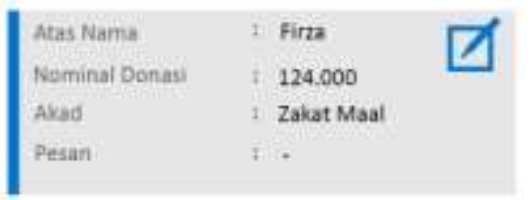

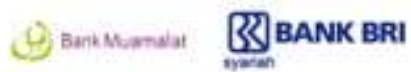
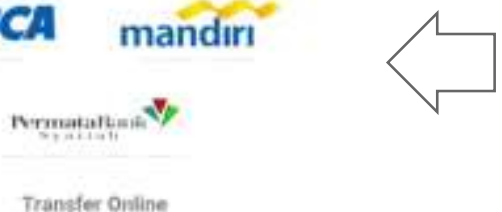

mandırı

Transter Online

CIMB Clicks

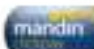

ePay BRI PermataRum,

VISA

Total :

Rp. 124.000 


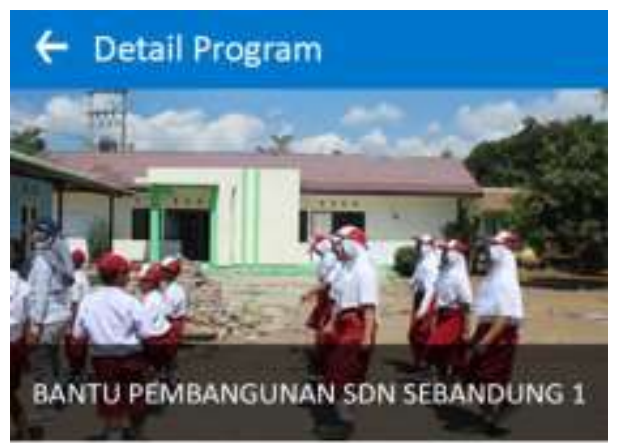

"Deskripsi Program

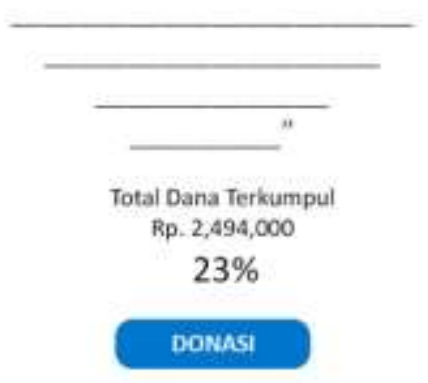

Dinaungi oleh Lembaga Lazisnu

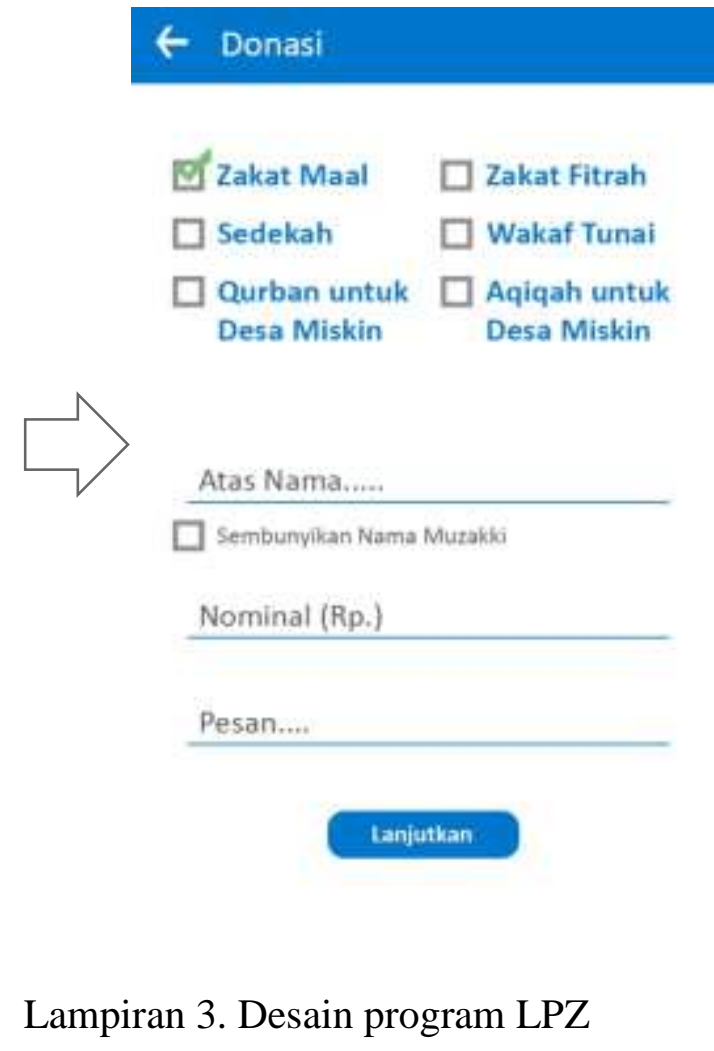

Lampiran 3. Desain program LPZ

\section{$\leftarrow$ Pilih Pembayaran}

\begin{tabular}{|c|c|}
\hline mandin & $\mathbb{N B N I ^ { \text { syariat } }}$ \\
\hline EcIMB NIAGA & $\mathbf{M}^{\text {BANMMEGA }}$ \\
\hline (9) BantMandat & खBANK BRI \\
\hline$\triangle B C A$ & mandırı \\
\hline
\end{tabular}

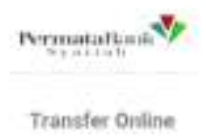

CIMB Clicks

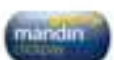

e-Pay BRI Purmatakinik $y$

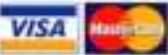



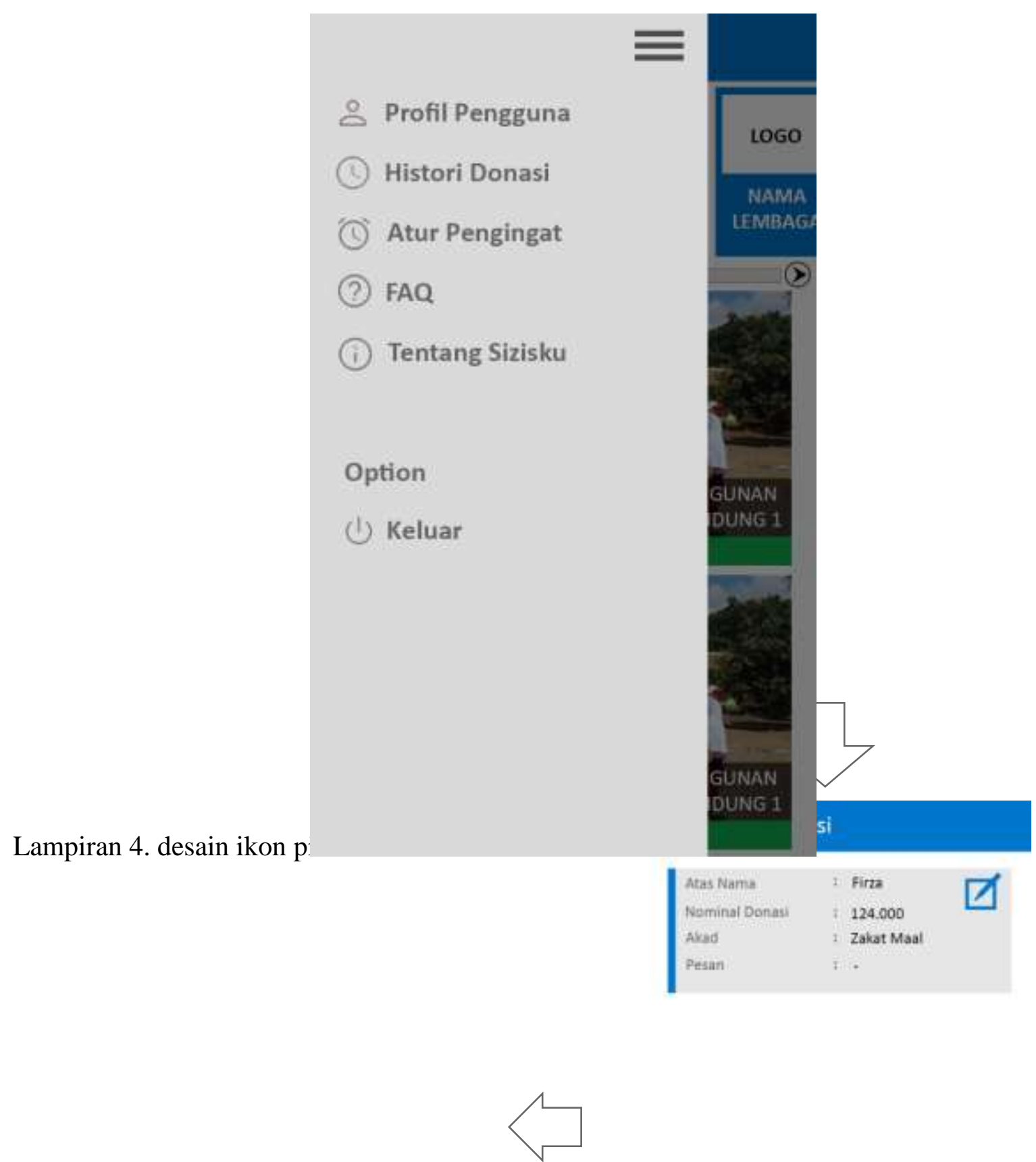
Lampiran 5. Desain history donasi

\section{$\leftarrow$ Histori Donasi}

$\begin{array}{lr}\text { Atas Nama } & \text { Detail Donasi } \\ \text { Firza } & \text { Zakat Maal } \\ \text { Metode Pembayaran } & \\ \text { BTN Mobile } & \text { Total Donas }\end{array}$

Rp. 124,000

Atas Nama

Selvi

Metode Pembayaran

BTN Mobile
Detail Donasi

Zakat Maal

Total Donasi

Rp. 324,000
Atas Nama

Anas

Metode Pembayaran

BTN Mobile
Detail Donasi

Zakat Maal

Total Donasi

Rp. 255,000
Atas Nama

Firza

Metode Pembayaran

BTN Mobile

\section{Detail Donasi}

Zakat Maal

Total Donasi

Rp. 124,000 


\section{Lampiran 6. Desain FAQ}

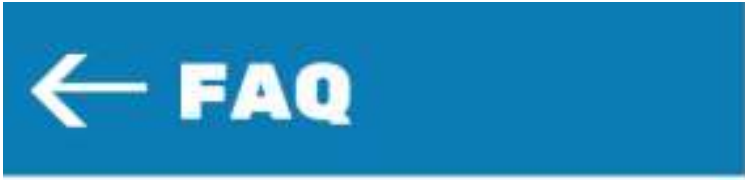

\section{Apa itu sizisku?}

sizisku merupakan aplikasi zakat yang mengintegrasi lembaga zakat nasional

Bagaimana cara kerja sizisku?

menghimpun data mustahiq dari setiap lembaga

\section{Bagaimana cara mendaftarkan}

diri sebagai Mustahik?

Klik menu register sebagai mustahiq

Bagaimana cara kerja sizisku?

menghimpun data mustahiq dari setiap lembaga 